\title{
Wage Led Aggregate Demand in the United Kingdom*
}

\author{
Robert Jump ${ }^{\dagger}$ \\ Ivan Mendieta-Muñoz
}

January 20, 2017

\begin{abstract}
The wage led aggregate demand hypothesis is examined for the United Kingdom over the period 1971 - 2007. Existing studies disagree on the aggregate demand regime for the UK, and this appears to be due to differing empirical approaches. Studies relying on equation-by-equation estimation procedures tend to find support for wage led aggregate demand in the UK, while the single study using a multiple time series estimation procedure finds no support for the hypothesis. We test the wage led aggregate demand hypothesis in the UK using VAR models estimated on quarterly data employing an alternative identification strategy based on shocks to real earnings. The results provide support for the wage led aggregate demand hypothesis during the period of study. However, the expansionary effects of higher earnings seem to be limited and relatively short-lived.
\end{abstract}

Keywords: Real Earnings, Income Distribution, Business Cycles.

JEL Codes: E32, E25, B50, E12.

\footnotetext{
${ }^{*}$ We would like to thank Matthieu Charpe, Vince Daly, Makram El-Shagi, Hans-Martin Krolzig, Miguel Leon-Ledesma, Özlem Onaran, Mathan Satchi, Ron Smith, Chris Stewart, Engelbert Stockhammer, and seminar participants at the 2015 IMK conference in Berlin, Kingston PERG, Leeds University Business School, and the Post Keynesian Study Group for invaluable suggestions for improvement. We would also like to thank two anonymous referees and the editor for their constructive comments. Any remaining errors are the responsibility of the authors.

${ }^{\dagger}$ Department of Economics, Kingston University, Penrhyn Road, Kingston upon Thames, Surrey, KT1 2EE, UK. Email: r.jump@kingston.ac.uk.

${ }_{\ddagger}^{\ddagger}$ Department of Economics, University of Utah, Room 213, Building 73, 332 South 1400 East, Salt Lake City, UT 84112, USA. Email: ivan.mendietamunoz@utah.edu.
} 


\section{Introduction}

The wage led aggregate demand hypothesis can be traced to the work of Michał Kalecki and Josef Steindl via Rowthorn (1981), Dutt (1984), and Bhaduri and Marglin (1990). The theoretical framework supposes that total consumption is an increasing function of the labour share, and total investment and net exports are decreasing functions of the labour share. Depending on the relative strength of these distributive effects, an increase in the labour share will either increase or decrease aggregate demand, and thereby gross domestic product (GDP). The wage led aggregate demand hypothesis states that the distributive effect on demand works in favour of wages: an increase in the labour share will lead to an increase in GDP.

The interplay between the distribution of income and the level of aggregate demand has been argued, by a number of prominent economists, to be of central importance in rethinking macroeconomic theory in light of the 2008 crisis (e.g. Stiglitz 2011). The wage led aggregate demand hypothesis itself has been influential in those policy-focused international institutions broadly aligned with developing countries and the labour movement (UNCTAD 2010, Lavoie and Stockhammer 2012). However, a variety of estimation procedures and data types have been used to test the hypothesis, and different studies often come to different conclusions. This is particularly the case in the UK. Studies relying on equation-by-equation estimation procedures, for example, tend to find support for wage led aggregate demand in the UK. This is the case in Bowles and Boyer (1995), Naastepad and Storm (2007), Hein and Vogel (2008), Onaran and Galanis (2014), and Obst and Onaran (2015). The single study using a multiple time series estimation procedure, Stockhammer and Onaran (2004), finds no support for the hypothesis.

This paper tests the wage led aggregate demand hypothesis in the UK using VAR models. Our approach implements an alternative identification strategy based on real earnings shocks, rather than the labour share or total labour income. Modelling the labour share directly almost forces the researcher to use identification restrictions based on the BhaduriMarglin model (or some adaptation of it), which is the approach taken in the bulk of the existing literature. Essentially, instead of identifying shocks to the labour share directly, we estimate movements in the labour share indirectly, by estimating the responses of GDP and total employment to shocks to real earnings.

Our focus in this paper is solely on short run changes in the functional income distribution, and we do not estimate long run relationships. This is, perhaps, the simplest approach to the wage led aggregate demand hypothesis, although it runs counter to arguments made in Blecker (2014). While we are not averse to the proposition that income distribution effects operate at low frequencies, it seems likely that the best way to approach this problem empirically would be to employ multiple time series models that estimate both short-term and long-term effects (such as error correction models), or via cross-country growth regressions. The foregoing, in addition, explains why we refer to the wage led aggregate demand hypothesis throughout the paper, rather than the wage led growth hypothesis as in Bhaduri (2008), as the latter puts more stress on the long run than we do in the present paper.

The rest of the paper is organised as follows. Section 2 discusses the wage led aggregate demand hypothesis in the context of movements in real earnings, rather than the labour share, and compares this to the existing literature. With this background, section 3 discusses our empirical approach. Section 4 discusses our data sources and variable definitions, and section 5 presents the estimation results. Section 6 concludes, and discusses the implications of our results for theory and policy. 


\section{The Wage Led Aggregate Demand Hypothesis}

Consider a general model of the business cycle, where the endogenous variables are consumption $(C)$, investment $(I)$, net exports $(X)$, and GDP $(Y)$. Assume that GDP is determined by the aggregate demand identity, and the components of aggregate demand are functions of GDP and the labour share $(h)$, such that,

$$
\begin{gathered}
Y=C+I+X, \\
C=C(Y, h), \\
I=I(Y, h), \\
X=X(Y, h),
\end{gathered}
$$

suppressing exogenous government spending. Therefore, the total derivative is given by,

$$
\frac{d Y}{d h}=\left(\frac{\partial C}{\partial h}+\frac{\partial I}{\partial h}+\frac{\partial X}{\partial h}\right)\left(1-\frac{\partial C}{\partial Y}-\frac{\partial I}{\partial Y}-\frac{\partial X}{\partial Y}\right)^{-1}
$$

Equation (5) summarises the wage led aggregate demand hypothesis. One usually assumes that the second term in brackets is positive, that consumption is increasing in the labour share, and that both investment and net exports are decreasing in the labour share. If the positive effect of an increase in the labour share on consumption outweighs any negative effects on investment and net exports, then the total effect on GDP will be positive.

There is a rather large literature testing the wage led aggregate demand hypothesis, the bulk of which estimates equations of the form (2) - (4) on an equation-by-equation basis. The studies that apply this method to UK data are Bowles and Boyer (1995), Naastepad and Storm (2007), Hein and Vogel (2008), Stockhammer and Stehrer (2011), Onaran and Galanis (2014), and Obst and Onaran (2015). All of these papers, apart from Stockhammer and Stehrer (2011), find that aggregate demand in the UK is wage led. In a lot of this literature, however, potential problems arise from assuming that the labour share is exogenous. While this is a legitimate procedure in a thought experiment of the sort described above, it is potentially problematic when testing the theory. In particular, it is possible that the assumption of exogenous regressors (that is, regressors that are not contemporaneously correlated with the error term) is not satisfied in a number of the existing equation-by-equation empirical studies, giving rise to the possibility of endogeneity bias.

While the issue of endogeneity bias is often discussed in the empirical literature, it is not often dealt with. Two possible solutions could be to estimate VAR models assuming a reduced form specification: 1) in the components of aggregate demand and the labour share; and 2) in GDP and the labour share, following the study of Barbosa-Filho and Taylor (2006) for the USA. Unfortunately, in both cases identification problems arise. Specifically, meaningful impulse response functions require orthogonal shock processes, and the notions of orthogonal GDP and labour share shocks is just as problematic as treating the labour share itself as exogenous. 
One notable solution to this conundrum is that of Stockhammer and Onaran (2004), which estimates a structural VAR model based explicitly on Bhaduri and Marglin (1990). This circumvents the problem of imagining orthogonal GDP and labour share shocks by an appeal to a structural model with a large number of degrees of freedom. The authors find that shocks to the functional distribution of income have essentially no effect on capacity utilisation, and thus find no support for the wage led aggregate demand hypothesis. This is an incongruous result made particularly worrying by the aforementioned estimation bias in the group of studies that find that the UK is wage led.

As with Stockhammer and Onaran (2004), we estimate VAR models for the UK. Unlike the latter, we take an indirect approach by disaggregating the labour share into real earnings, total employment, and GDP. We are then left with a model in GDP $(Y)$, total employment $(L)$, and real earnings $(w)$,

$$
\begin{aligned}
& Y=Y(w, L), \\
& L=L(w, Y), \\
& w=w(Y, L) .
\end{aligned}
$$

Here, (6) is an aggregate demand curve, (7) is an employment curve, and (8) is an earnings curve. While we expect the earnings curve to be increasing in both GDP and employment, both $\partial Y / \partial w$ and $\partial L / \partial w$ are ambiguous. If the former is positive, then a positive shock to the earnings curve increases aggregate demand. This case is illustrated in the left panel of figure 1, which plots an upward sloping earnings curve and upward sloping aggregate demand curve in $(w, Y)$ space.

Given the above, we take advantage of the fact that exogenous changes in the labour share in the heterodox perspective are usually held to be driven by changes in workers' bargaining power. This view is summarised in the following passage discussing policies associated with the wage led aggregate demand hypothesis:

"Pro-labour policies. . . are often referred to as policies that strengthen the welfare state, labour market institutions, labour unions, and the ability to engage in collective bargaining (e.g., by extending the reach of bargaining agreements to non-unionised firms). Pro-labour policies are also associated with increased unemployment benefits, higher minimum wages and a higher minimum wage relative to the median wage, as well as reductions in wage and salary dispersion" (Lavoie and Stockhammer 2012).

FIGURE 1 ABOUT HERE. CAPTION: Illustrating the wage led aggregate demand hypothesis.

In light of this, we will interpret real earnings shocks as bargaining power shocks. We will then consider the data to be consistent with the wage led aggregate demand hypothesis if positive real earnings shocks lead to increases in both GDP and the labour share. This case 
is illustrated in the right panel of figure 1, under the assumption that the change in total employment is non-negative and $\partial w / \partial Y=0$. Thus we take an indirect approach to testing the wage led aggregate demand hypothesis, avoiding issues of endogeneity bias and the need to construct orthogonal GDP and labour share shocks.

This approach is dissimilar to the existing literature testing the wage led aggregate demand hypothesis, and may be compared to the econometric literature studying the relationship of real wages, output, and employment over the business cycle. Brandolini (1995) provides a comprehensive survey of this literature up to the early 1990s. A notable recent study is McFarlane et al (2014), which studies the business cycle co-movements of Canadian wages, output, and employment, using the VAR methodology. In addition, we may usefully compare our approach to the New Keynesian theories of real wages and aggregate demand, where exogenous movements in the real wage can be driven by productivity shocks as well as bargaining power shocks. An example is Balmaseda et al (2000), which finds that positive real wage shocks increase aggregate demand, but these shocks are interpreted as productivity shocks rather than bargaining power shocks.

While our approach is formally similar to the econometric literature surveyed in Brandolini (1995) and the New Keynesian literature, it must be stressed that our goal is very different. Unlike these literatures, we are not primarily concerned with the relationship between output and the real wage (or real earnings). Instead, we are primarily concerned with the relationship between output and the labour share, and will only consider the data to be consistent with the wage led aggregate demand hypothesis if positive real earnings shocks lead to increases in both GDP and the labour share. This is not often a concern of the aforementioned literatures, for which the functional distribution of income is not considered important on the demand side, although there is an issue of observational equivalence to bear in mind ${ }^{1}$. This is discussed with the data in section 4, after our empirical approach is discussed in section 3 .

\section{Empirical Approach}

As discussed in section 2, we model movements in real earnings rather than the labour share, and follow Stockhammer and Onaran (2004) by estimating the following,

$$
\begin{gathered}
A z_{t}=\alpha+\sum_{i=1}^{p} A_{i} z_{t-i}+u_{t}, \\
z_{t}=\mu+\sum_{i=1}^{p} C_{i} z_{t-i}+\epsilon_{t}
\end{gathered}
$$

where (9) is the structural model, and (10) is the reduced form. The vector $z_{t}$ contains GDP, total employment, and real earnings, $u_{t}$ is a white noise vector process with $u_{t} \sim N(0, I)$,

\footnotetext{
${ }^{1}$ Positive wage shocks in New Keynesian models usually reduce output on impact. Interestingly, however, a weak wage led aggregate demand mechanism is incorporated into the Bank of England's COMPASS model, where a wage mark-up shock "temporarily increases labour income and consumption of [liquidity] constrained households, which is sufficient to increase total consumption in the near term. This effect means that GDP does not fall immediately" (Burgess et al 2013a, 2013b: B17). Also see Charpe and Kühn (2015).
} 
and $\epsilon_{t}$ is a white noise vector process with $\epsilon_{t} \sim N(0, \Sigma)$. This leads to an identification problem: recovering $A$ from the estimated reduced form (10). From (9) and (10) we have $\epsilon_{t}=A^{-1} u_{t}$, or $A \epsilon_{t}=u_{t}$. Expanding, we have:

$$
\left(\begin{array}{lll}
a_{11} & a_{12} & a_{13} \\
a_{21} & a_{22} & a_{23} \\
a_{31} & a_{32} & a_{33}
\end{array}\right)\left(\begin{array}{c}
\epsilon_{w} \\
\epsilon_{Y} \\
\epsilon_{L}
\end{array}\right)=\left(\begin{array}{l}
u_{w} \\
u_{Y} \\
u_{L}
\end{array}\right)
$$

We use a simple Cholesky decomposition to solve this problem. Specifically, we assume $a_{12}=a_{13}=a_{23}=0$, thus (11) reduces to,

$$
\left(\begin{array}{ccc}
a_{11} & 0 & 0 \\
a_{21} & a_{22} & 0 \\
a_{31} & a_{32} & a_{33}
\end{array}\right)\left(\begin{array}{c}
\epsilon_{w} \\
\epsilon_{Y} \\
\epsilon_{L}
\end{array}\right)=\left(\begin{array}{l}
u_{w} \\
u_{Y} \\
u_{L}
\end{array}\right)
$$

The restrictions embodied in (12) imply that real earnings do not react to GDP or employment within the period, GDP reacts to real earnings but not employment within the period, and employment reacts to both real earnings and GDP within the period. Real earnings are the "most exogenous" variable in the system, which is consistent with the Post Keynesian approach to wage led aggregate demand discussed above. This is the most important assumption in (12), as we will be focusing on real earnings shocks, and it can be justified by a number of arguments. First, it is well established that nominal wage and price contracts are updated infrequently and set in advance of production (see e.g. Druant et al (2012) and the list of references presented in that paper). In addition, the relevant output and employment data are released with a lag, and are subject to substantial uncertainty concerning future revision. Finally, wage setting is known to depend on a number of largely non-economic considerations, including notions of fairness that evolve very slowly (Bewley 1999).

As stated in the introduction, we are only concerned with the short run effects of real earnings shocks in the present paper, which we explore with impulse response functions using the Cholesky decomposition described here. Note, however, that the VAR methodology that we use does not impose any restrictions on the long run effects of shocks, and we report the accumulated impulse response functions in section 5. In particular, it is important to point out that we do not make any assumptions concerning a long run equilibrium labour share. To do so, as pointed out in the introduction, would require an error correction model and cointegration analysis.

\section{Data}

\subsection{Sources}

FIGURE 2 ABOUT HERE. CAPTION: NSA Real GDP, SA total employment, and NSA real earnings series, four quarter log differences, 1972 - 2007. 
FIGURE 3 ABOUT HERE. CAPTION: NSA GDP and NSA labour share approximation, four quarter log differences, 1972 - 2007.

As explained in sections 2 and 3, we estimate VARs in GDP, total employment, and real earnings. The raw data are as follows: non-seasonally adjusted (NSA) quarterly nominal GDP from the UK quarterly national accounts (code BKTL), seasonally adjusted (SA) nominal GDP from the quarterly national accounts (code YBHA), NSA UK real (chain value) GDP from the quarterly national accounts (code BKVT), SA UK real (chain value) GDP from the quarterly national accounts (code ABMI), SA total employment from the Labour Force Survey, NSA average weekly earnings from the ONS Employment and Earnings publications (codes MD9M and KA46), and the NSA retail price index from the ONS MM23 Consumer Price Indices publication (code CDKO). Only the GDP series are available both SA and NSA; the historical earnings and price data are only available NSA, and the employment data are only available SA (as the quarterly data are interpolated on an SA basis prior to 1992). Note that the earnings series exclude incomes of the self-employed and members of the armed forces.

Given the above, we construct two NSA real earnings series using average earnings deflated by the retail price index and average earnings deflated by the NSA GDP deflator, where the latter is given by the ratio of NSA nominal and NSA real GDP. We then seasonally adjust these NSA real earnings series using the automated Census X-13 procedure in EViews, which yields two SA real earnings series. We can then estimate four VARs in total: two VARs using NSA real GDP, NSA real earnings, and SA total employment (where the first uses RPI deflated earnings, and the second uses GDP deflated earnings), and two VARs using SA real GDP, SA real earnings, and SA total employment (where the first uses RPI deflated earnings, and the second uses GDP deflated earnings). Thus we use SA and NSA data, and two different earnings deflators, to increase the robustness of our results. All of the series run from 1971 to 2014, although on inspection there appears to be a large structural break in the real earnings series around 2008, which causes fairly serious problems for our estimates. As our VARs require relatively long lag lengths (see below), testing for the structural break is relatively difficult; after experimenting with different options, we chose to limit our sample size to end at 2007Q4.

\subsection{Unit Roots Tests}

With respect to the SA data, three different unit root tests were employed to determine the order of integration of the series: the Augmented Dickey-Fuller test (ADF; Said and Dickey 1984); the Dickey-Fuller Generalized Least Squares test (DF-GLS; Elliot et al. 1996); and the Modified Phillips-Perron test (M-PP; Ng and Perron 2001). We employed OLSdetrended data as the autoregressive spectral estimation method in the M-PP test since, according to Perron and Qu (2007), this method can be considered as a solution to the drawback that (for non-local alternatives) the power of the M-PP tests can be very small. The highest lag order $\left(l_{\max }\right)$ selected to carry out the three tests was determined from the sample size according to the method proposed by Schwert $(1989): l_{\max }=\left[12(144 / 100)^{0.25}\right] \approx 13$. We employed different methods to determine the optimal lag order in each test: the Schwarz information criterion was employed for the ADF test, the general-to-specific procedure (Ng and Perron 1995) was employed for the DF-GLS test, and the Modified Akaike Information Criterion (Ng and Perron 2001) was employed for the M-PP test. 
Table A1 in the appendix reports the different linear unit root tests, which were carried out including a constant and a trend as exogenous regressors for the different series. The tests shows that it is not possible to reject the null hypothesis of a unit root at the $5 \%$ level of significance in the majority of the log-levels of the series, and that the null hypothesis is rejected when the first differences of the log-levels of the series are considered. Hence, it is possible to conclude that the growth rates of the series can be characterised as $I(0)$ processes.

With respect to the NSA data, we employed the HEGY test for seasonal unit roots (Hylleberg et al 1990), using the HEGY test add-in for EViews. This tests for unit roots at seasonal frequencies, indicating how the data should be differenced (in order to prevent over-differencing and the incorporation of artificial moving average components). The test results are presented in Table A2 in the appendix. All tests were carried out including a constant, a trend, and seasonal dummies as exogenous regressors for the different series. The different tests show that none of the log-levels of the series can be considered as stationary series since the null hypotheses that $\pi_{1}=0, \pi_{2}=0$ and $\pi_{3}=\pi_{4}=0$ are not rejected (see Hylleberg et al 1990) ${ }^{2}$. Likewise, it is possible to observe that the four-quarter differences of the log-levels of series can be considered as stationary series since the null hypotheses that $\pi_{1}=0, \pi_{2}=0$ and $\pi_{3}=\pi_{4}=0$ are not rejected.

As discussed above, we estimate four VARs in total: two VARs using NSA real GDP, NSA real earnings, and SA total employment (where the first uses RPI deflated earnings, and the second uses GDP deflated earnings), and two VARs using SA real GDP, SA real earnings, and SA total employment (where the first uses RPI deflated earnings, and the second uses GDP deflated earnings). Given the results of the unit roots tests, all variables in the first two VARs are in four quarter log differences, and all variables in the second two VARs are in one quarter log differences.

\subsection{Description}

Figure 2 plots the four quarter log differences of NSA real GDP, NSA real earnings, and SA total employment, from 1972 - 2007. While real earnings appear to be mildly pro-cyclical and less volatile than GDP, total employment follows GDP with a considerable lag and is much less volatile than GDP, even allowing for the interpolated data prior to 1992. The real earnings series appear to differ slightly depending on the deflator used, with the differences being most pronounced in the late 1970s and late 1990s. Figure 3 plots four quarter log differences of NSA real GDP and the NSA labour share, where the latter is approximated by the four quarter log difference of NSA real earnings plus the four quarter log difference of SA total employment minus the four quarter log difference of NSA real GDP. This figure illustrates the well known counter-cyclicality of the labour share, in contrast with the mild pro-cyclicality of real earnings illustrated in figure 2 .

FIGURE 4 ABOUT HERE. CAPTION: NSA real earnings and SA hours per person, four quarter log differences, 1972 - 2007.

Two final points must be noted. First, the wage led aggregate demand hypothesis, as we interpret it, requires a positive real earnings shock to increase both GDP and the labour

\footnotetext{
${ }^{2}$ There appears to be no non-seasonal unit root in the log-level of the GDP deflated earnings since the null hypothesis that $\pi_{1}=0$ is rejected in this case. The slight ambiguities in the unit root tests should not create too much doubt in the inference, however, as all series are expected to be non-stationary.
} 
share, which might appear inconsistent with the counter-cyclicality of the labour share at first glance. However, all this implies is that shocks to real earnings that increase both the labour share and GDP cannot be a significant source of fluctuations in either variable, and the wage led aggregate demand hypothesis is thus perfectly consistent with a countercyclical labour share. This conjecture, in fact, is supported by the variance decomposition analyses presented in section 5. Second, average earnings are given by the average hourly wage multiplied by average hours worked per person, and thus it is possible that the mild pro-cyclicality of real earnings is driven in the main by pro-cyclical hours worked. Moreover, a positive shock to real earnings could be interpreted as a positive shock to hours worked per person, which does not support an interpretation of earnings shocks as bargaining power shocks. However, we have good reason to believe that the bulk of fluctuations in average weekly earnings are accounted for by fluctuations in the hourly wage. Figure 4 plots the four quarter log difference of NSA average weekly earnings deflated by the RPI deflator and the four quarter log difference of an estimate of SA weekly hours worked per person (total weekly hours, LFS code YBUS, divided by total employment as above). The hours series is considerably less volatile than the real earnings series over the majority of the sample, and the contemporaneous correlation coefficient between the two series is negative and not significantly different from zero at the $5 \%$ level. Thus we expect the bulk of fluctuations in real earnings to be due to real wage fluctuations, and we do not expect positive shocks to real earnings to be the result of increases in hours worked ${ }^{3}$.

\section{Results}

\subsection{Reduced Form Estimates}

As discussed in sections 2, 3 and 4, we estimate VAR models in GDP, total employment, and real earnings. We estimate four reduced form VARs in total: two VARs using NSA real GDP, NSA real earnings, and SA total employment (where the first uses RPI deflated earnings, and the second uses GDP deflated earnings), and two VARs using SA real GDP, SA real earnings, and SA total employment (where the first uses RPI deflated earnings, and the second uses GDP deflated earnings). All series in the first two VARs are in four quarter log differences, and all series in the second two VARs are in one quarter log differences, following the unit root tests described in section 4.

First, we estimate the two reduced form VARs with NSA real GDP, NSA real earnings, and SA total employment, where the first uses RPI deflated earnings, and the second uses GDP deflated earnings. The AIC lag length criteria for both the RPI deflator model and the GDP deflator model indicate 10 lags, and 10 lags also results in reasonable statistics for residual autocorrelation. Both models with 10 lags are stable, with all roots lying within the unit circle. In addition, we cannot reject the null of homoskedasticity using the White test for either model. Although the simple reduced form models appear to be well specified in terms of residual autocorrelation and heteroskedasticity, residual normality test results are unsatisfactory. Bearing this in mind, we choose 10 lags for both reduced form VARs. Detailed tables of results for the specification tests can be found in table B1 in the appendix.

\footnotetext{
${ }^{3}$ Our results are robust to replacing the weekly earnings series with an estimated hourly earnings series constructed using the ONS hours data, although this reduces our ability to infer labour share movements from the results.
} 
Second, we estimate the two reduced form VARs with SA real GDP, SA real earnings, and SA total employment, where the first uses RPI deflated earnings, and the second uses GDP deflated earnings. The AIC lag length criteria for both the RPI deflator model and the GDP deflator model indicate 3 lags, but both models with 3 lags appear to suffer from residual autocorrelation and heteroskedasticity. However, reasonable statistics for residual autocorrelation and heteroskedasticity are achieved in models with 10 lags as before (although the RPI deflator model suffers from heteroskedasticity problems even with 10 lags). Both models with 10 lags are stable, with all roots lying within the unit circle. Finally, both models again suffer from residual normality problems ${ }^{4}$. Bearing this in mind, we choose 10 lags for both reduced form VARs. Detailed tables of results for the specification tests can be found in table B2 in the appendix.

FIGURE 5 ABOUT HERE. CAPTION: Impulse response functions of GDP (top), employment (middle), earnings (bottom), to a positive real earnings shock, VARs with NSA real GDP, NSA real earnings, and SA total employment (four quarter log differences). Left panel: RPI deflated earnings, right panel: GDP deflated earnings.

FIGURE 6 ABOUT HERE. CAPTION: Impulse response functions of GDP (top), employment (middle), earnings (bottom), to a positive real earnings shock, VARs with SA real GDP, SA real earnings, and SA total employment (one quarter log differences). Left panel: RPI deflated earnings, right panel: GDP deflated earnings.

FIGURE 7 ABOUT HERE. CAPTION: Accumulated impulse response functions of GDP (top), employment (middle), earnings (bottom), to a positive real earnings shock, VARs with NSA real GDP, NSA real earnings, and SA total employment (four quarter log differences). Left panel: RPI deflated earnings, right panel: GDP deflated earnings.

FIGURE 8 ABOUT HERE. CAPTION: Accumulated impulse response functions of GDP (top), employment (middle), earnings (bottom), to a positive real earnings shock, VARs with SA real GDP, SA real earnings, and SA total employment (one quarter log differences). Left panel: RPI deflated earnings, right panel: GDP deflated earnings.

\subsection{Impulse Response Functions}

As discussed in section 3, we rely on Cholesky decompositions to isolate shocks to real earnings. Figure 5 plots the impulse response functions and $95 \%$ confidence bands $^{5}$, for all three variables, for the models with NSA real GDP, NSA real earnings, and SA total employment. We plot the responses for the model with RPI deflated earnings in the left three panels, and responses for the model with GDP deflated earnings in the right three panels. It is immediately apparent that a positive real earnings shock causes an increase in GDP on impact, and has no significant effect on total employment. The differences between the two sets of impulse response functions are minor, with the obvious difference being the larger effect of the real earnings shock on GDP in the model with GDP deflated earnings.

\footnotetext{
${ }^{4}$ We added dummy variables in previous specifications to deal with this problem, which was more successful in the models with NSA data than with SA data. The results were not materially affected, however, so the final specifications do not include dummy variables.

${ }^{5}$ All confidence bands shown in Figures 5 and 6 were computed using the bootstrap procedure in EViews with 1000 repetitions.
} 
Aside from this, both sets of impulse response functions imply that the positive effect on GDP growth of a real earnings shock declines to zero after a year, and that the effect on total employment is negligible ${ }^{6}$.

Figure 6 plots the impulse response functions and 95\% confidence bands, for all three variables, for the models with SA real GDP, SA real earnings, and SA total employment. Again, we plot the responses for the model with RPI deflated earnings in the left three panels, and responses for the model with GDP deflated earnings in the right three panels. As in the models with NSA data, a positive real earnings shock causes an increase in GDP on impact, and has no significant effect on total employment. The differences between the two sets of impulse response functions are minor, and the effects of a real earnings shock on GDP at impact are similar to those in the models with NSA data. The largest difference between the impulse response functions in the models with SA data and the models with NSA data is the length of the effect: a positive real earnings shock appears to have a positive effect on GDP that only lasts a single quarter in the models using SA data.

The conclusion that positive shocks to real earnings increase aggregate demand does not, by itself, lead to the conclusion that the wage led aggregate demand hypothesis is supported. As noted in section 2, we also require that the labour share increases in response to an exogenous increase in real earnings. As total employment does not respond significantly to real earnings shocks in figures 5 and 6 , and the response of real earnings is uniformly greater than the response of aggregate demand, then we can say with confidence that both aggregate demand and the labour share increase in response to a real earnings shock in the United Kingdom. At the mean, from figures 5 and 6 , our results indicate that a $1 \%$ shock to real earnings should increase the labour share by approximately $0.5 \%$ to $0.7 \%$, and GDP by approximately $0.3 \%$ to $0.5 \%$. At the lower end of our $95 \%$ confidence bands, our results indicate that a $1 \%$ shock to real earnings should increase the labour share by approximately $0.75 \%$ to $0.8 \%$, and GDP by approximately $0.2 \%$ to $0.25 \%$. Given this, we conclude that the data are consistent with the wage led aggregate demand hypothesis.

However, the positive effect of a real earnings shock on GDP appears to be short lived. Figures 7 and 8 plot the cumulated counterparts to the impulse response functions presented in figures 5 and 6 . One can observe that the permanent effects of a real earnings shock on GDP and employment are positive but relatively small, and at the $5 \%$ level are not significantly different from zero. Thus our results indicate that wage led aggregate demand effects operate at relatively high frequencies.

Finally, it was noted in section 4 that the labour share is counter-cyclical, despite the result that shocks to real earnings increase both GDP and the labour share. This implies that shocks to real earnings cannot account for a significant proportion of GDP movements, which is confirmed by the forecast error variance decompositions in table 1 for the VAR models with NSA real GDP, NSA real earnings, and SA total employment (the decompositions for the models with SA real GDP, SA real earnings, and SA total employment are similar). From this table we can see that higher proportions of the variation in GDP can be explained by real earnings shocks when using the GDP deflator. Shocks to real earnings explain at most $31.49 \%$ of the error in the forecast of GDP, corresponding to the first-quarter horizon when the VAR is estimated using GDP deflated earnings. In the long run, real earnings shocks explain less than $20 \%$ of the variation in GDP and total employment. These results support our previous conjecture that shocks to real earnings explain a relatively small proportion of the variance in GDP. Therefore, while positive real earnings shocks result in an increase in

\footnotetext{
${ }^{6}$ Note the labels in figures 5 - 8 are the EViews workfile labels; we have provided a table in appendix C to facilitate comparison of the graphs and use of the workfile, which is available from the authors on request.
} 
Table 1: Forecast error variance decompositions ${ }^{\mathrm{a}}$

\begin{tabular}{|c|c|c|c|}
\hline Forecast Horizon & GDP & Employment & Earnings \\
\hline \multicolumn{4}{|c|}{ VAR using RPI deflated earnings ${ }^{\mathrm{b}}$} \\
\hline 1 & 18.15 & 1.09 & 100.00 \\
\hline 2 & 16.90 & 0.94 & 99.37 \\
\hline 4 & 15.89 & 3.47 & 98.42 \\
\hline 8 & 14.13 & 10.76 & 84.21 \\
\hline 100 & 16.39 & 14.48 & 72.61 \\
\hline \multicolumn{4}{|c|}{$V A R$ using GDP deflated earnings ${ }^{\mathrm{b}}$} \\
\hline 1 & 31.49 & 3.74 & 100.00 \\
\hline 2 & 28.72 & 4.39 & 97.84 \\
\hline 4 & 21.53 & 6.85 & 97.34 \\
\hline 8 & 18.92 & 11.50 & 92.51 \\
\hline 100 & 17.41 & 13.22 & 84.28 \\
\hline
\end{tabular}

Notes: ${ }^{a}$ We show the results of GDP, employment, and real earnings to shocks in real earnings for the VAR using NSA data; ${ }^{b}$ Percentage points are shown.

both GDP and the labour share, these shocks do not account for a large proportion of GDP movements, such that the observed labour share in the UK is countercyclical.

\subsection{Robustness of Results}

As discussed in section 3, we rely on Cholesky decompositions to draw our conclusions, and the specific Cholesky decomposition chosen cannot be tested using the sample data. As a result, it is important to check the robustness of the results to alternative decompositions. For all of the data specifications used in this study, the conclusions remain the same for any Cholesky decomposition in which earnings are ordered before GDP. However, the conclusions are altered if a Cholesky decomposition is chosen in which earnings are ordered after GDP. In these cases, there is no evidence of wage led aggregate demand, as GDP appears to be unaffected by movements in earnings. The position of total employment in the decomposition does not affect the conclusions. Finally, our results are robust to using generalised impulse response functions rather than orthogonal impulse response functions.

Our results are not, therefore, completely robust to the choice of impulse response function. However, it is important to note that there are no possible Cholesky decompositions in which an increase in real earnings leads to a statistically significant reduction in GDP growth - an increase in earnings appears to have either a short-lived positive effect (in our preferred specification) or zero effect. In addition, it appears to us to be much more reasonable to assume that earnings are relatively slow moving in comparison to total output in the UK, hence why we concentrate on the Cholesky decomposition described in section 3. 


\section{Concluding Remarks}

This paper starts with the observation that the wage led aggregate demand hypothesis has been tested in the UK using a variety of estimation procedures. Studies relying on equationby-equation estimation procedures tend to find support for wage led aggregate demand in the UK, while the single study using a multiple time series estimation procedure finds no support for the hypothesis. We test the wage led aggregate demand hypothesis using VAR models estimated on quarterly data employing an alternative identification strategy based on real earnings shocks. The estimation results show that positive shocks to real earnings increase both GDP and the labour share, indicating that aggregate demand in the UK is wage led. However, the expansionary effects of higher earnings seem to be limited and relatively short-lived by our estimates, and there is very little impact on total employment. Finally, the results are not entirely robust to the choice of impulse response function.

One possible avenue for future research is to take a more expansive approach to the effects of wage shocks on the major macroeconomic variables. This will require a treatment of nominal wage and price inflation, which we do not provide in the present paper. A second is to explore the link between employment and the labour share in more detail, which might be amenable to direct estimation. Finally, one could estimate non-linear models to investigate the effects of earnings or wage shocks at different stages of the business cycle. 


\section{References}

[1] Akerlof, G., \& Yellen, J. 1986. Efficiency Wage Models Of The Labor Market. Cambridge: Cambridge University Press.

[2] Atkinson, A. 1969. The timescale of economic models: How long is the long run? The Review of Economic Studies, 36, 137-152.

[3] Balmaseda, M., Dolado, J., and Lopez-Salido, J. 2000. The dynamic effects of shocks to labour markets: evidence from OECD countries. Oxford Economic Papers, 3-23.

[4] Barbosa-Filho, N., and Taylor, L. 2006. Distributive and demand cycles in the US economy - a structuralist Goodwin model. Metroeconomica 57.3: 389-411.

[5] Barbosa-Filho, N. 2015. Elasticity of substitution and social conflict: a structuralist note on Piketty's Capital in the Twenty-first Century. Cambridge Journal of Economics, DOI: $10.1093 /$ cje/bev042.

[6] Bewley, T. 1999. Why wages don't fall during a recession. Harvard: Harvard University Press.

[7] Bhaduri, A. 2008. On the dynamics of profit-led and wage-led growth. Cambridge Journal of Economics, 32, 147-160.

[8] Bhaduri, A., and Marglin, S. 1990. Unemployment and the real wage: the economic basis for contesting political ideologies. Cambridge Journal of Economics, 14, 375-93.

[9] Blecker, R. 2014. Wage-led versus profit-led demand regimes: The long and the short of it. Working Paper.

[10] Bowles, S., and Boyer, R. 1995. Wages, aggregate demand, and employment in an open economy: an empirical investigation. In Macroeconomic policy after the conservative era, Cambridge University Press, Cambridge, 143-71.

[11] Brandolini, A. 1995. In search of a stylised fact: do real wages exhibit a consistent pattern of cyclical variability? Journal of Economic Surveys 9, 103-163.

[12] Burgess , S., Fernandez-Corugedo, E., Groth, C., Harrison, R., Monti, F., Theodoridis, K., and Waldron, M. 2013a. The Bank of England's forecasting platform: COMPASS, MAPS, EASE, and the suite of models. Bank of England Working Paper 471.

[13] Burgess , S., Fernandez-Corugedo, E., Groth, C., Harrison, R., Monti, F., Theodoridis, K., and Waldron, M. 2013b. The Bank of England's forecasting platform: COMPASS, MAPS, EASE, and the suite of models. Appendices to Bank of England Working Paper 471.

[14] Charpe, M., and Kühn, S. 2015. Demand and supply effects of bargaining power shocks. Economic Modelling, 51, 21-32.

[15] Druant, M., Fabiani, S., Kezdi, G., Lamo, A., Martins, F., and Sabbatini, R. 2012. Firms' price and wage adjustment in Europe: Survey evidence on nominal stickiness. Labour Economics, 19, 772-782. 
[16] Dutt, A. 1984. Stagnation, Income Distribution and Monopoly Power. Cambridge Journal of Economics, 8, 25-40.

[17] Ederer, S., and Stockhammer, E. 2007. Wages and aggregate demand in France: An empirical investigation. 119-138, in Hein, E., and Truger, A. (eds), Money, Distribution, and Economic Policy - Alternatives to Orthodox Macroeconomics. Cheltenham: Edward Elgar.

[18] Elliott, G., Rothemberg, T. and Stock, J. 1996. Efficient tests for an autoregressive unit root. Econometrica 64.4, 813-836.

[19] Hartwig, J. 2014. Testing the Bhaduri-Marglin model with OECD panel data. International Review of Applied Economics 28.4, 419-435.

[20] Hein, E., and Vogel, L. 2008. Distribution and growth reconsidered - empirical results for six OECD countries. Cambridge Journal of Economics, 32, 479-511.

[21] Hylleberg, S., Engle, R., Granger, C. and Yoo, B., 1990. Seasonal integration and cointegration. Journal of Econometrics, 44.1-2, 215-238.

[22] Lavoie, M. and Stockhammer, E. 2012. Wage-led growth: Concept, theories and policies. Basingstoke: Palgrave Macmillan.

[23] MacKinnon, J. 1996. Numerical distribution functions for unit root and cointegration tests. Journal of Applied Econometrics, 11.6, 601-618.

[24] McFarlane, A., Das, A,, and Chowdhury, M. 2014. Non-linear dynamics of employment, output and real wages in Canada: Recent time series evidence. Journal of Economic Studies, 41, 554-568.

[25] Naastepad, C. and Storm, S. 2007. OECD demand regimes (1960-2000). Journal of Post-Keynesian Economics, 29, 213-248.

[26] Ng, S. and Perron, P. 1995. Unit root tests in ARMA models with data-dependent methods for the selection of the truncation lag. Journal of the American Statistical Association 90.429, 268-281.

[27] Ng, S. and Perron, P. 2001. Lag length selection and the construction of unit root tests with good size and power. Econometrica 69.6, 1519-1554.

[28] Obst, T., and Onaran, Ö. 2015. Wage-led growth in the EU15 Member States: The effects of income distribution on growth, investment, trade balance, and inflation. FEPS Working Paper, Foundation for European Progressive Studies.

[29] Onaran, Ö, Stockhammer, E., and Grafl, L. 2011. The finance-dominated growth regime, distribution, and aggregate demand in the US. Cambridge Journal of Economics 35.4, 637-661.

[30] Onaran, Ö. and Galanis, G. 2014. Income distribution and growth: a global model. Environment and Planning A, 46.10: 2489-2513.

[31] Onaran, Ö, and Stockhammer, E. 2005. Two different export-oriented growth strategies: accumulation and distribution a la Turca and a la South Korea. Emerging Markets Finance and Trade 41.1, 65-89. 
[32] Perron, P. and Qu, Z. 2007. A simple modification to improve the finite sample properties of $\mathrm{Ng}$ and Perron's unit root tests. Economics Letters 94.1, 12-19.

[33] Rowthorn, R. 1981. Demand, Real Wages and Economic Growth, Thames Papers in Political Economy, Autumn 1-39, reprinted in Studi Economici, 1982, 18, 3-54.

[34] Said, S. and Dickey, D. 1984. Testing for unit roots in autoregressive-moving average models of unknown order. Biometrika 71.(3): 599-607.

[35] Schwert, W. 1989. Tests for unit roots: a Monte Carlo investigation. Journal of Business and Economic Statistics 7.2, 147-159.

[36] Stiglitz, J. 2011. Rethinking macroeconomics: What failed, and how to repair it. Journal of the European Economic Association, 9.4, 591-645.

[37] Stockhammer, E., and Onaran, Ö. 2004. Accumulation, distribution and employment: a structural VAR approach to a Kaleckian macro-model. Structural Change and Economic Dynamics, 15, 421-47.

[38] Stockhammer, E., and Stehrer, R. 2011. Goodwin or Kalecki in Demand? Functional Income Distribution and Aggregate Demand in the Short Run. Review of Radical Political Economics, 43.4, 506-522.

[39] Stockhammer, E., Onaran, Ö., and Ederer, S. 2009. Functional income distribution and aggregate demand in the Euro area. Cambridge journal of Economics 33.1, 139-159.

[40] Stockhammer, E., Hein, E., and Grafl, L. 2011. Globalization and the effects of changes in functional income distribution on aggregate demand in Germany. International Review of Applied Economics, 25.1, 1-23.

[41] Tavani, D., Flaschel, P., and Taylor, L. 2011. Estimated non-linearities and multiple equilibria in a model of distributive-demand cycles. International Review of Applied Economics 25.5: 519-538.

[42] UNCTAD. 2010. Trade and Development Report 2010: Employment, Globalization and Development. UNCTAD: Geneva. 


\section{A Unit root tests}

Table A1: Linear unit root tests on seasonally adjusted data

\begin{tabular}{lccc}
\hline \hline & $\mathrm{ADF}^{\mathrm{a}, \mathrm{b}}$ & $\mathrm{DF}-G L S^{\mathrm{a}, \mathrm{b}}$ & $\mathrm{M}-\mathrm{PP} \mathrm{a}^{\mathrm{a} b}$ \\
\hline Log-levels & & & \\
GDP & $-3.36^{*}$ & $-2.84^{*}$ & $-19.84^{* *}$ \\
Employment & -1.91 & -2.36 & -8.19 \\
Earnings (RPI deflator) & -1.62 & -1.89 & -7.05 \\
Earnings (GDP deflator) & $-3.77^{* *}$ & -2.54 & -9.84 \\
First differences of the log-levels & & \\
GDP & $-5.46^{* *}$ & $-3.87^{* *}$ & $-25.36^{* * *}$ \\
Employment & -3.08 & $-3.19^{* *}$ & $-18.25^{* *}$ \\
Earnings (RPI deflator) & $-4.11^{* * *}$ & $-5.58^{* * *}$ & $-48.70^{* *}$ \\
Earnings (GDP deflator) & $-3.73^{* *}$ & $-11.89^{* * *}$ & $-68.75^{* * *}$ \\
\hline \hline
\end{tabular}

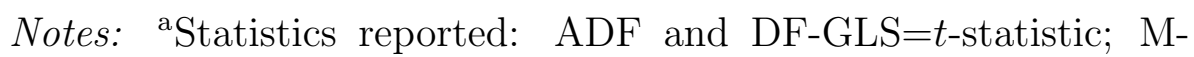
$\mathrm{PP}=$ MZa-statistic; ${ }^{\mathrm{b}}$ Critical values used: $\mathrm{ADF}=$ MacKinnon (1996) one-sided p-values; DF-GLS=Table 1 of Elliot et al. (1996); M$\mathrm{PP}=$ Table 1 of $\mathrm{Ng}$ and Perron (2001). *, **, and *** respectively denote rejection of the null hypothesis at the $10 \%, 5 \%$, and $1 \%$ significance levels.

Table A2: HEGY tests on non-seasonally adjusted data

\begin{tabular}{lccc}
\hline \hline & $\pi_{1}=0^{\mathrm{a}}$ & $\pi_{2}=0^{\mathrm{a}}$ & $\pi_{3}=\pi_{4}=0^{\mathrm{a}}$ \\
\hline Log-levels & \multicolumn{3}{c}{} \\
GDP & -2.54 & -0.94 & 3.07 \\
Earnings (RPI deflator) & 1.57 & 0.01 & 0.02 \\
Earnings (GDP deflator) & $-3.61^{* *}$ & -0.62 & 1.70 \\
Four-quarter differences of the log-levels & \\
GDP & $-4.08^{* * *}$ & $-6.21^{* * *}$ & $49.34^{* * *}$ \\
Employment & $-3.31^{*}$ & $-4.26^{* * *}$ & $33.14^{* * *}$ \\
Earnings (RPI deflator) & $-4.49^{* * *}$ & $-3.86^{* * *}$ & $32.86^{* * *}$ \\
Earnings (GDP deflator) & $-4.76^{* * *}$ & $-3.84^{* * *}$ & $25.29^{* * *}$ \\
\hline \hline
\end{tabular}

Notes: ${ }^{a}$ P-values were obtained from Monte Carlo simulations (2000 replications). Lag length selected according to the Akaike information criterion. $*, * *$, and $* * *$ respectively denote rejection of the null hypothesis at the $10 \%, 5 \%$, and $1 \%$ significance levels. 


\section{B Joint misspecification tests}

Table B1: Misspecification tests over VAR models with NSA data ${ }^{a}$

\begin{tabular}{|c|c|c|c|c|c|}
\hline \multicolumn{2}{|c|}{ Autocorrelation $^{\mathrm{b}}$} & \multicolumn{2}{|c|}{ Heteroskedasticity } & \multicolumn{2}{|c|}{ Normality } \\
\hline Statistic & $p$-value & $\chi^{2}$ statistic & $p$-value & Statistic & $p$-value \\
\hline \multicolumn{6}{|c|}{$V A R$ using RPI deflated earnings } \\
\hline 16.79 & 0.052 & 396.93 & 0.09 & 95.31 & 0 \\
\hline \multicolumn{6}{|c|}{ VAR using GDP deflated earnings } \\
\hline 12.74 & 0.17 & 289.34 & 0.99 & 42.00 & 0 \\
\hline
\end{tabular}

Notes: aTests employed: Serial correlation=Lagrange Multiplier; Heteroskedasticity $=$ White (no cross terms); Normality $=$ Cholesky of covariance (Lutkepohl); ${ }^{b}$ We only report the results that test for first-order serial correlation.

Table B2: Misspecification tests over VAR models with SA data ${ }^{a}$

\begin{tabular}{|c|c|c|c|c|c|}
\hline \multicolumn{2}{|c|}{ Autocorrelation ${ }^{\mathrm{b}}$} & \multicolumn{2}{|c|}{ Heteroskedasticity } & \multicolumn{2}{|c|}{ Normality } \\
\hline Statistic & $p$-value & $\chi^{2}$ statistic & $p$-value & Statistic & $p$-value \\
\hline \multicolumn{6}{|c|}{$V A R$ using RPI deflated earnings } \\
\hline 7.45 & 0.59 & 426.42 & 0.009 & 30.79 & 0 \\
\hline \multicolumn{6}{|c|}{$V A R$ using GDP deflated earnings } \\
\hline 8.32 & 0.50 & 367.81 & 0.38 & 31.63 & 0 \\
\hline
\end{tabular}

Notes: aTests employed: Serial correlation=Lagrange Multiplier; Heteroskedasticity $=$ White (no cross terms); Normality $=$ Cholesky of covariance (Lutkepohl); ${ }^{b}$ We only report the results that test for first-order serial correlation. 


\section{Variable labels in EViews workfile}

Table D1: Variable labels in EViews workfile and figures 5 - 8

\begin{tabular}{|c|c|}
\hline Variable label & Variable description \\
\hline DLGDP_NSA & $\begin{array}{l}\text { four quarter log difference of non seasonally adjusted } \\
\text { real GDP }\end{array}$ \\
\hline DLWAGE_RPI_NSA & $\begin{array}{l}\text { four quarter log difference of non seasonally adjusted } \\
\text { real earnings, RPI deflator }\end{array}$ \\
\hline DLWAGE_GDP_NSA & $\begin{array}{l}\text { four quarter log difference of non seasonally adjusted } \\
\text { real earnings, GDP deflator }\end{array}$ \\
\hline DLEMP & $\begin{array}{l}\text { four quarter log difference of seasonally adjusted total } \\
\text { employment }\end{array}$ \\
\hline DLGDP_SA & $\begin{array}{l}\text { one quarter log difference of seasonally adjusted real } \\
\text { GDP }\end{array}$ \\
\hline DLWAGE_RPI_SA & $\begin{array}{l}\text { one quarter log difference of seasonally adjusted real } \\
\text { earnings, RPI deflator }\end{array}$ \\
\hline DLWAGE_GDP_SA & $\begin{array}{l}\text { one quarter log difference of seasonally adjusted real } \\
\text { earnings, RPI deflator }\end{array}$ \\
\hline DLEMP1 & $\begin{array}{l}\text { one quarter log difference of seasonally adjusted total } \\
\text { employment }\end{array}$ \\
\hline
\end{tabular}



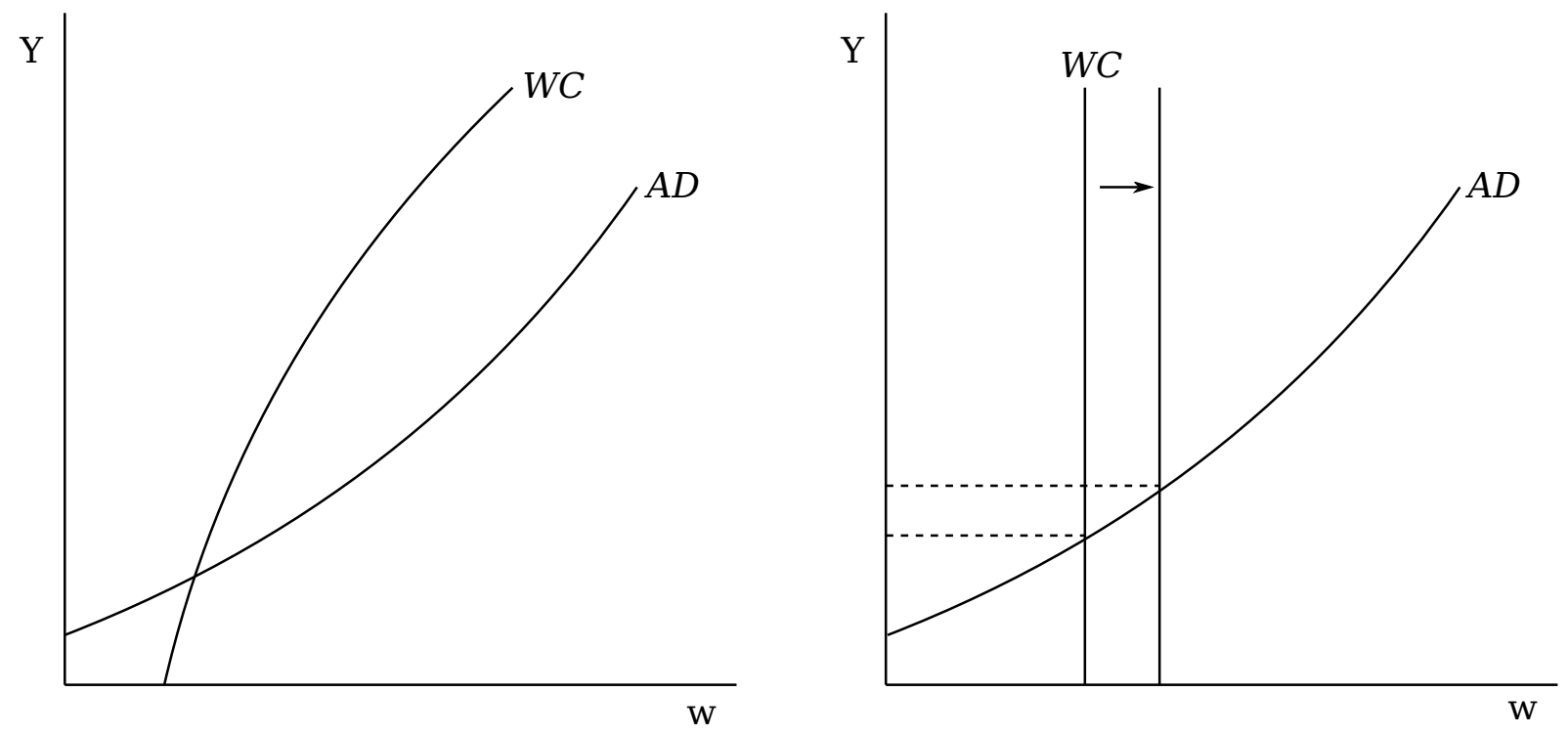

Figure 1 

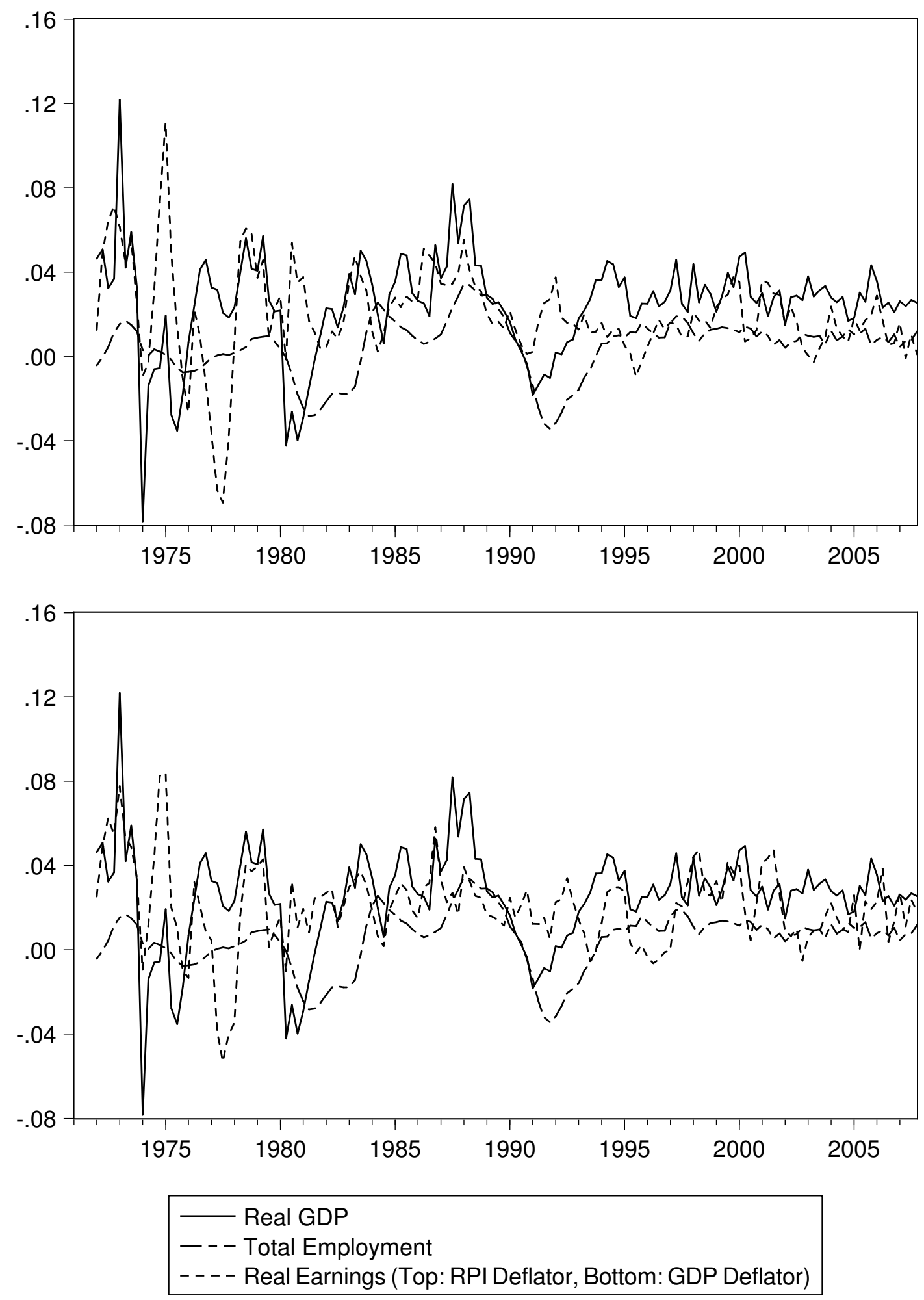

Figure 2 

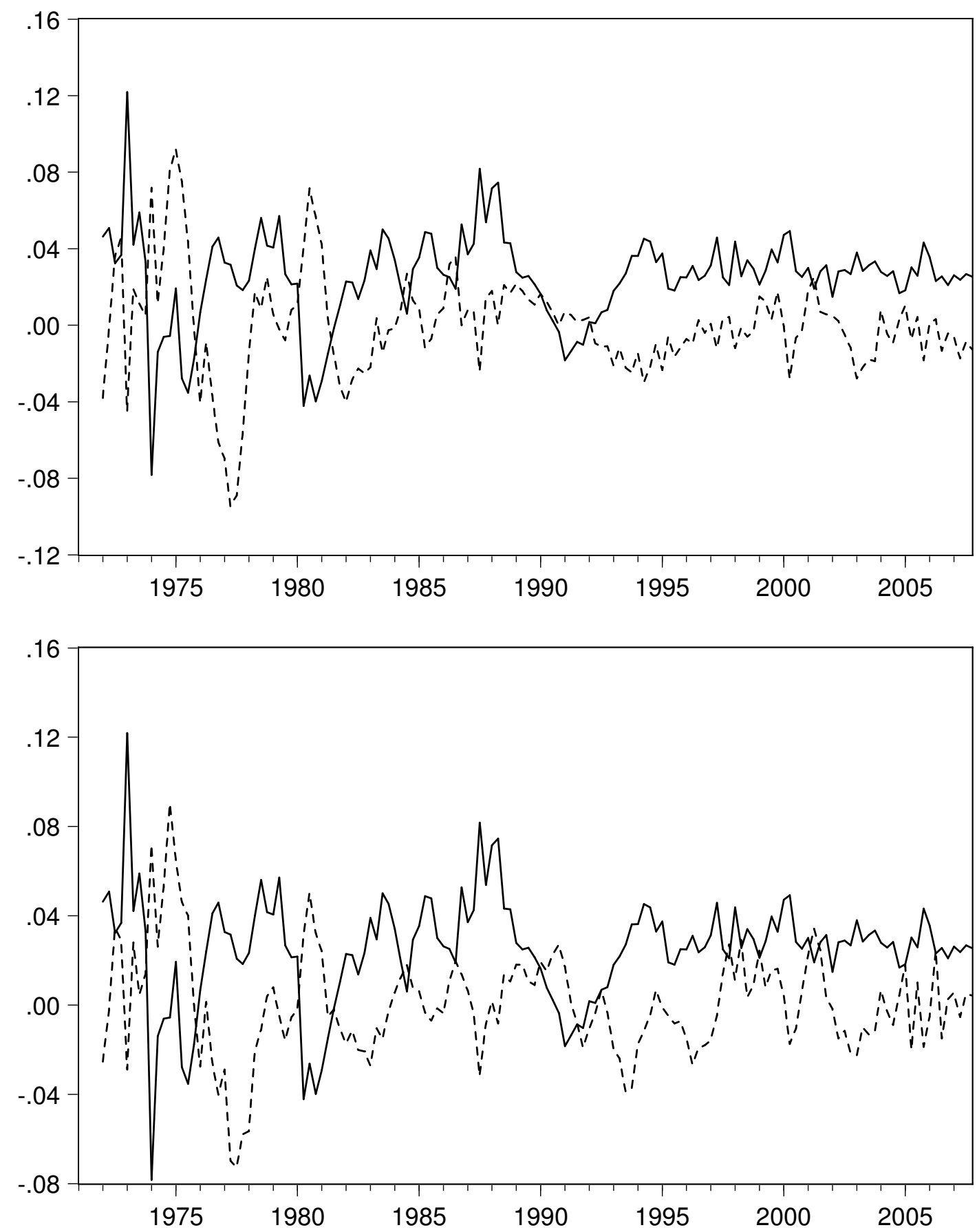

Real GDP

Labour Share (Top: RPI Deflator, Bottom: GDP Deflator)

Figure 3 


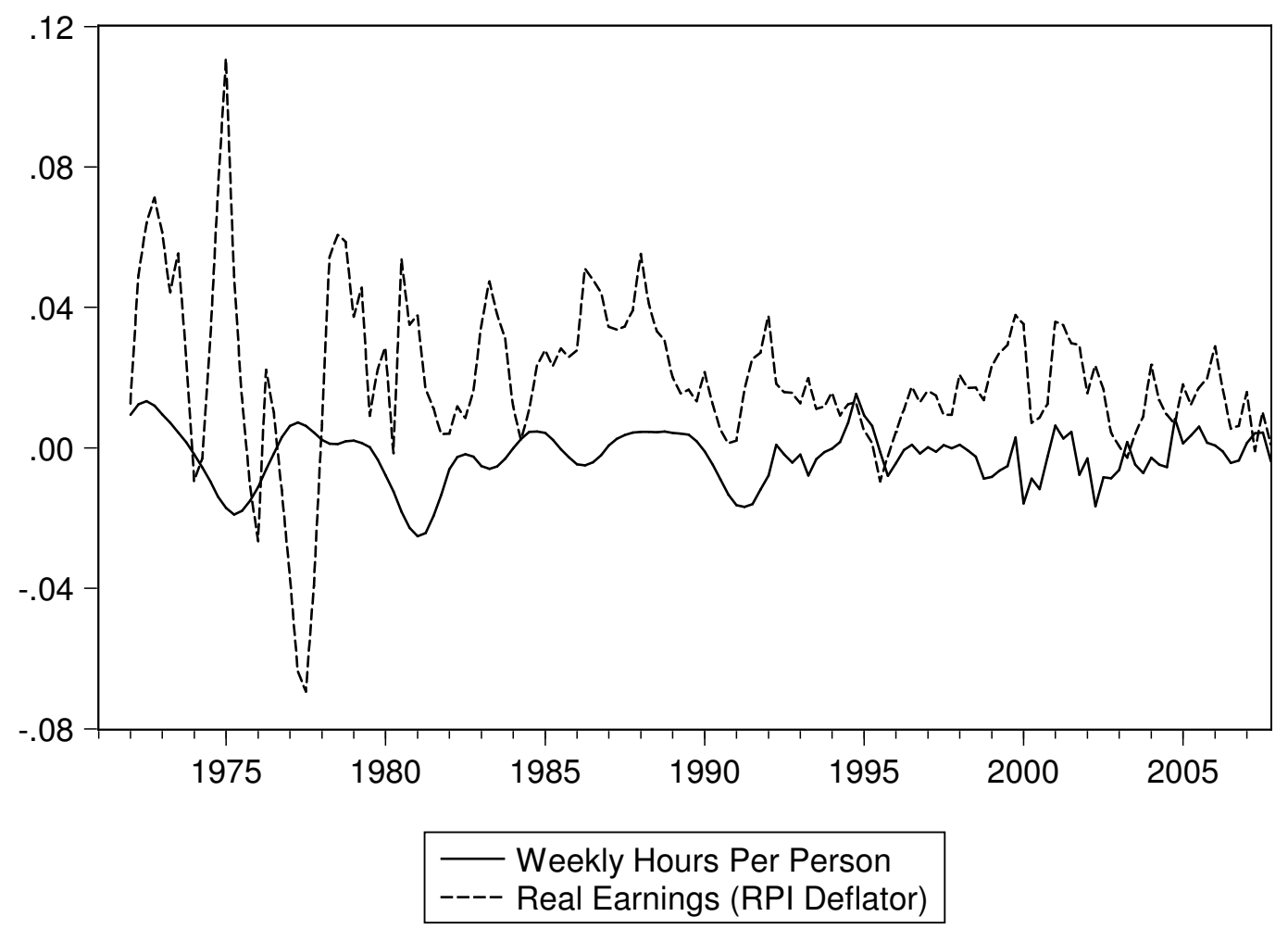

Figure 4 
Response of DLGDP NSA to Cholesky One S.D. DLWAGE RPI NSA Innovation

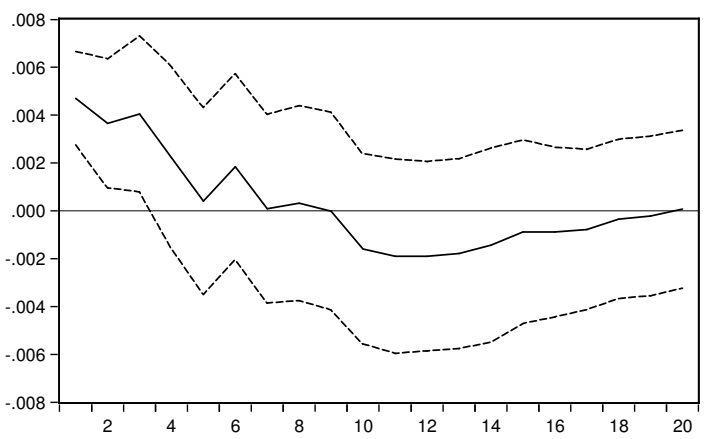

Response of DLEMP to Cholesky

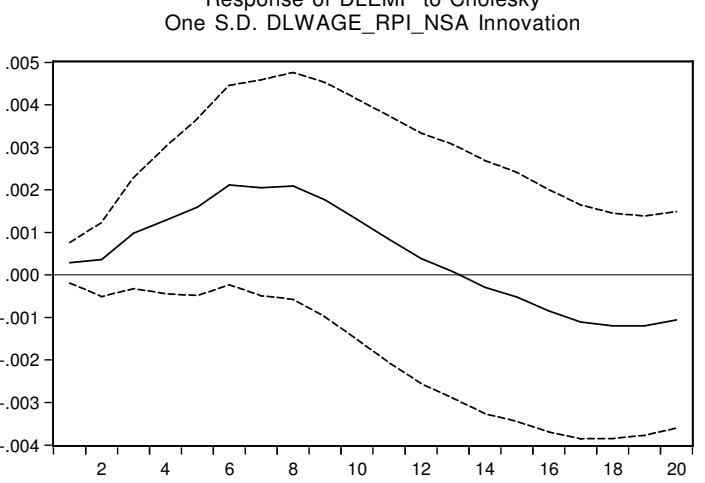

Response of DLWAGE RPI NSA to Cholesky One S.D. DLWAGE RPI NSA Innovation

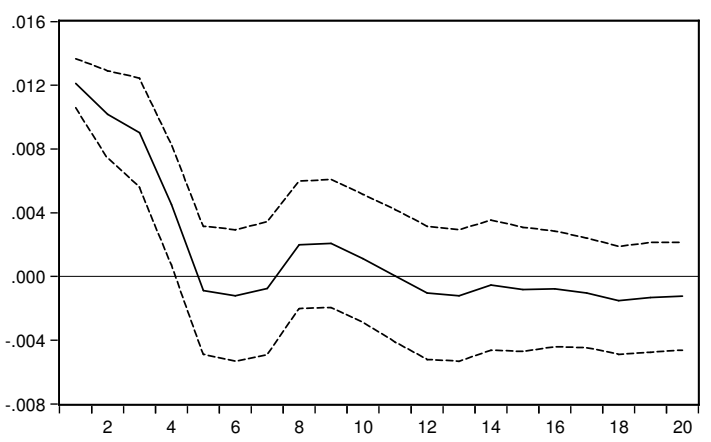

Response of DLGDP NSA to Cholesky One S.D. DLWAGE GDP NSA Innovation

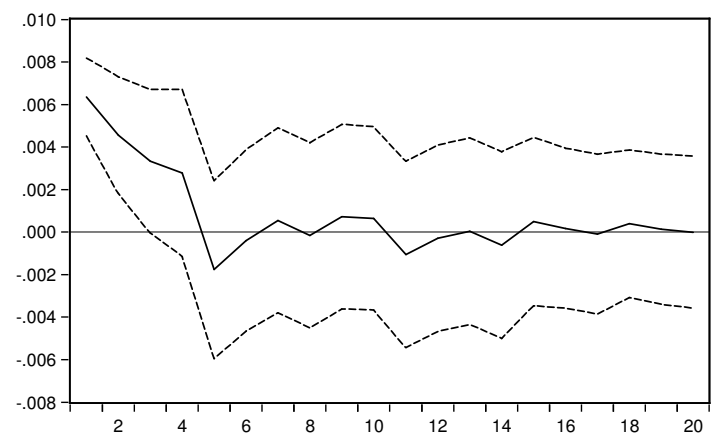

Response of DLEMP to Cholesky One S.D. DLWAGE_GDP_NSA Innovation

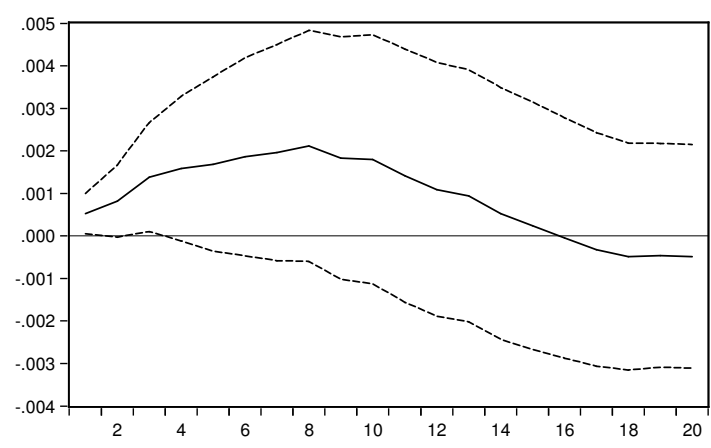

Response of DLWAGE_GDP_NSA to Cholesky One S.D. DLWAGE_GDP_NSA Innovation

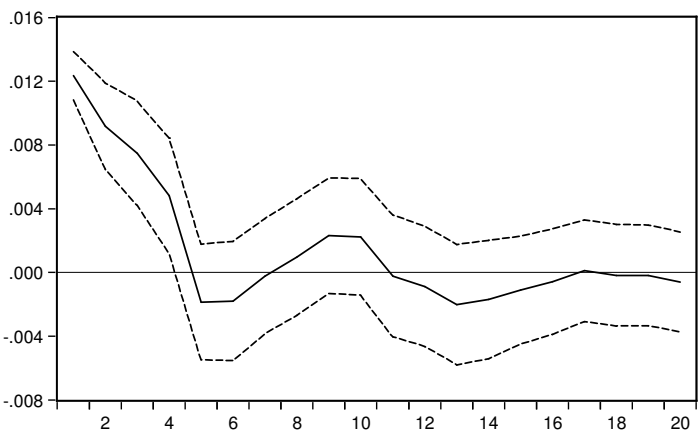

Figure 5 

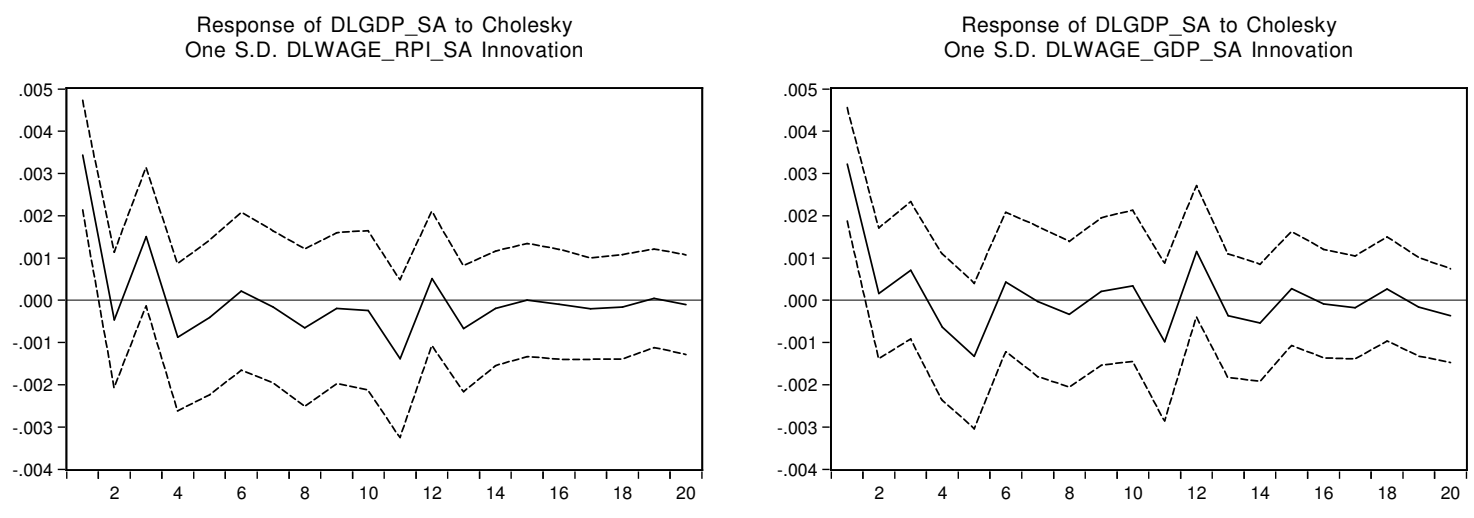

Response of DLEMP1 to Cholesky One S.D. DLWAGE_RPI_SA Innovation

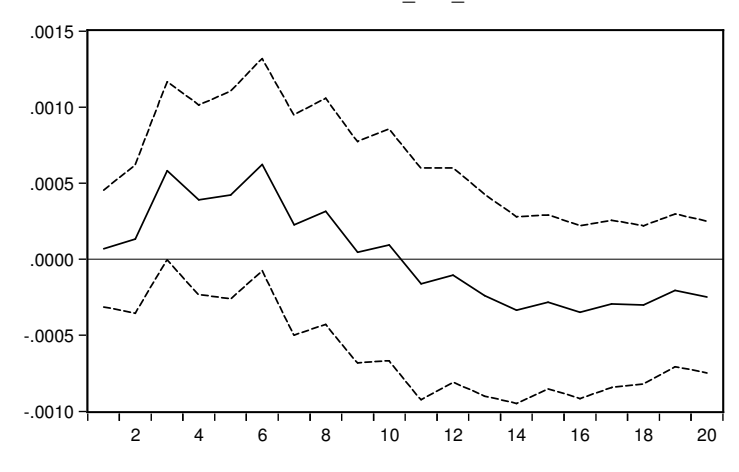

Response of DLEMP1 to Cholesky

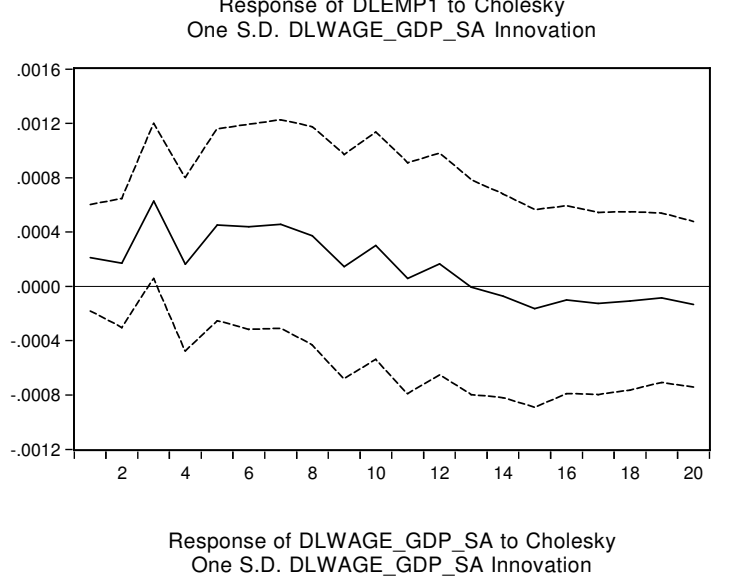

Response of DLWAGE_RPI_SA to Cholesky One S.D. DLWAGE_RPI_SA Innovation
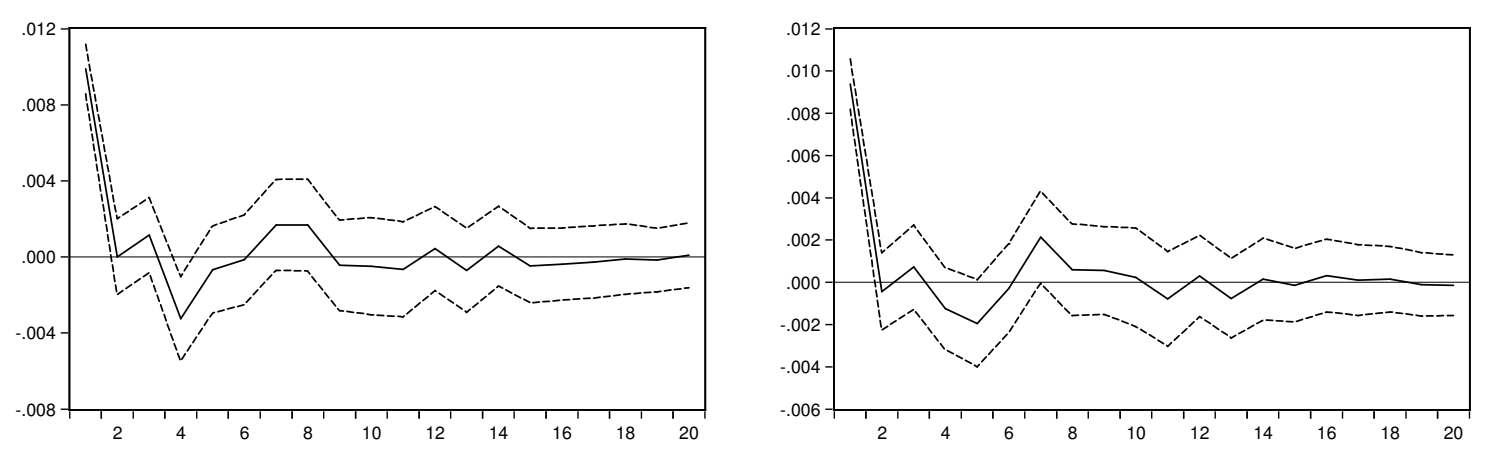

Figure 6 
Accumulated Response of DLGDP NSA to Cholesky One S.D. DLWAGE_RPI_NSA Innovation

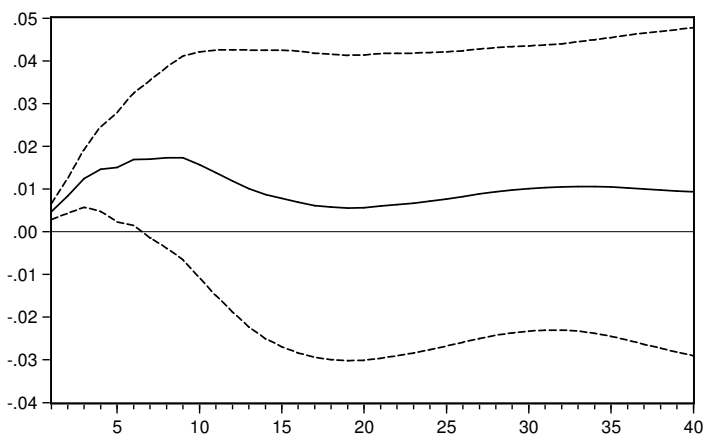

Accumulated Response of DLEMP to Cholesk One S.D. DLWAGE_RPI_NSA Innovation

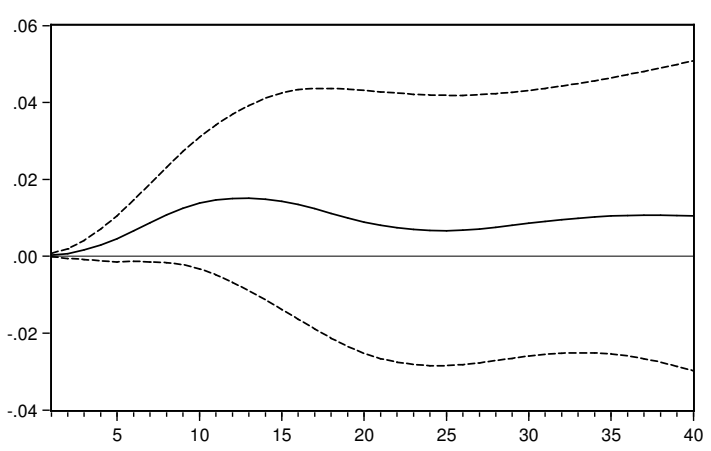

Accumulated Response of DLWAGE_RPI_NSA to Cholesky One S.D. DLWAGE RPI NSA Innovation

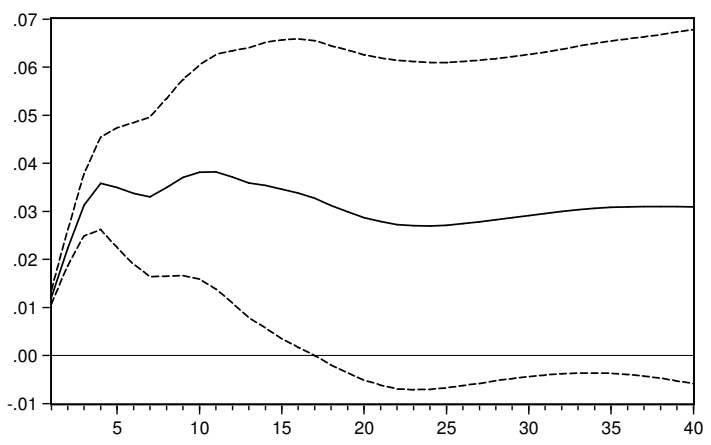

Accumulated Response of DLGDP NSA to Cholesky One S.D. DLWAGE_GDP_NSA Innovation

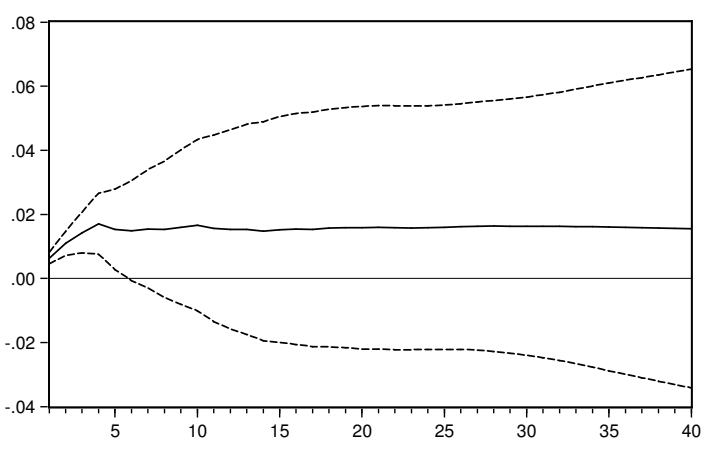

Accumulated Response of DLEMP to Cholesk One S.D. DLWAGE_GDP_NSA Innovation

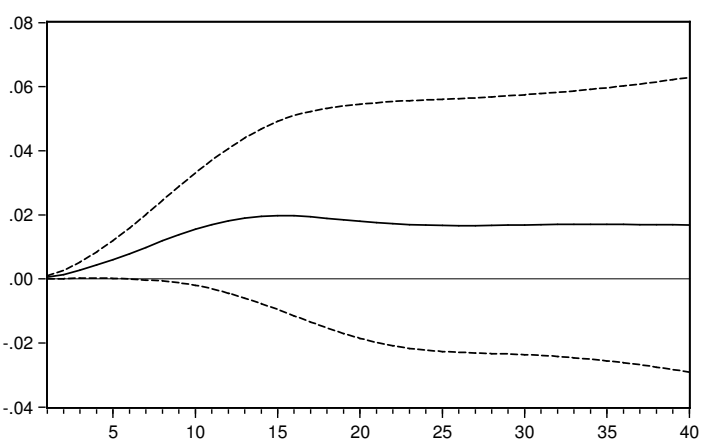

Accumulated Response of DLWAGE_GDP_NSA to Cholesky One S.D. DLWAGE GDP NSA Innovation

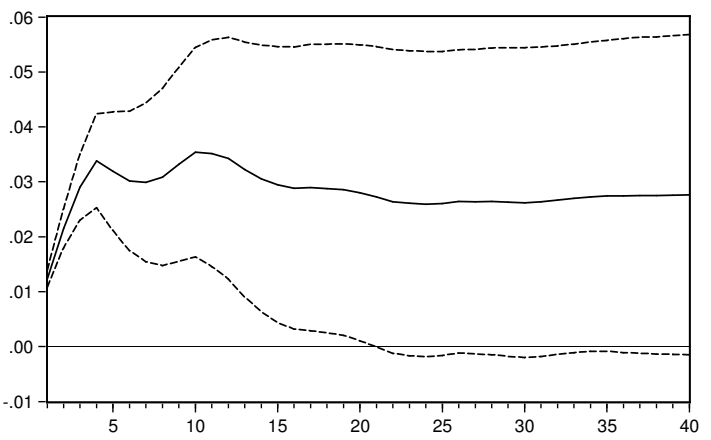

Figure 7 

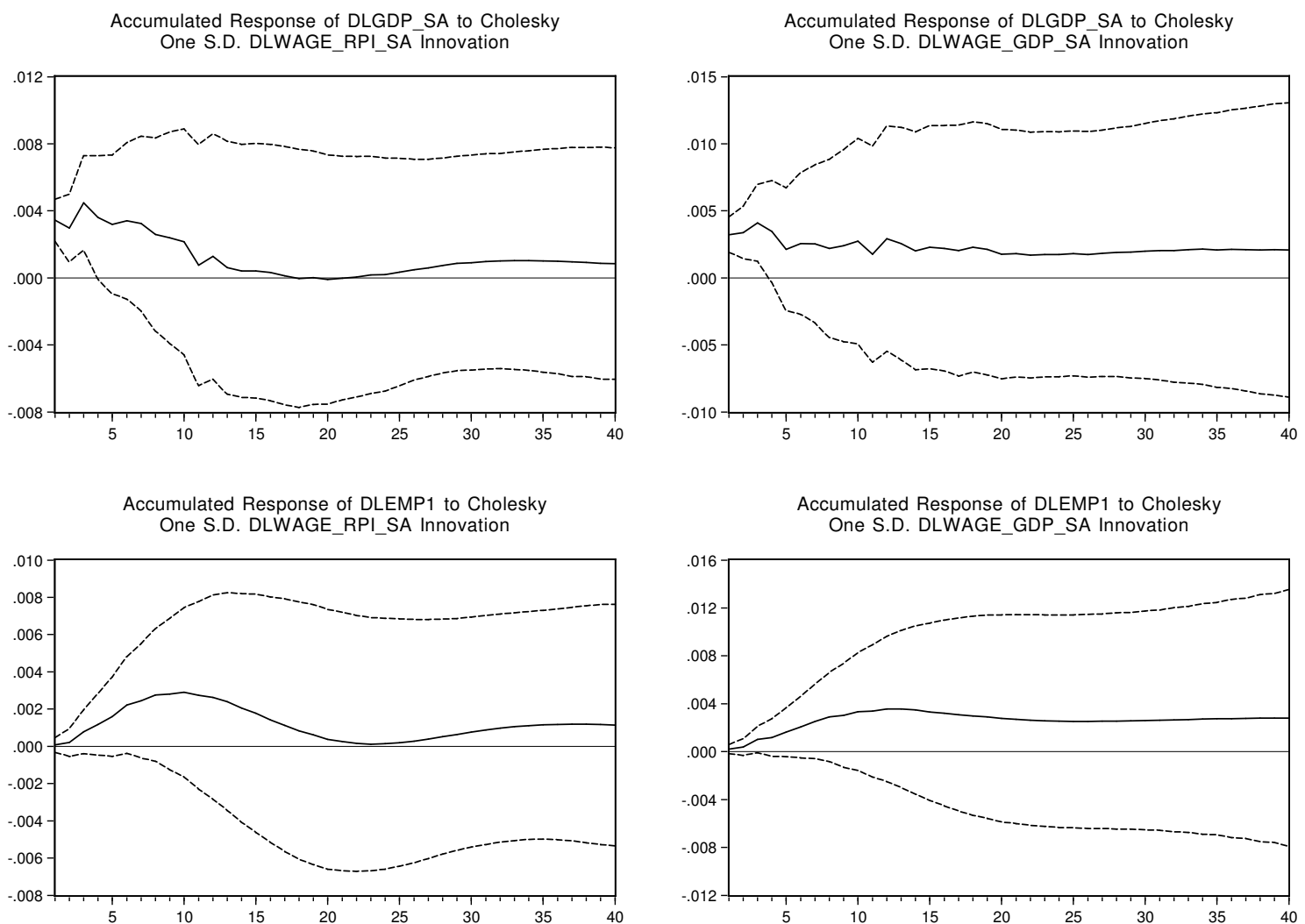

Accumulated Response of DLWAGE_RPI_SA to Cholesky One S.D. DLWAGE_RPI_SA Innovation

Accumulated Response of DLWAGE_GDP_SA to Cholesky One S.D. DLWAGE_GDP_SA Innovation
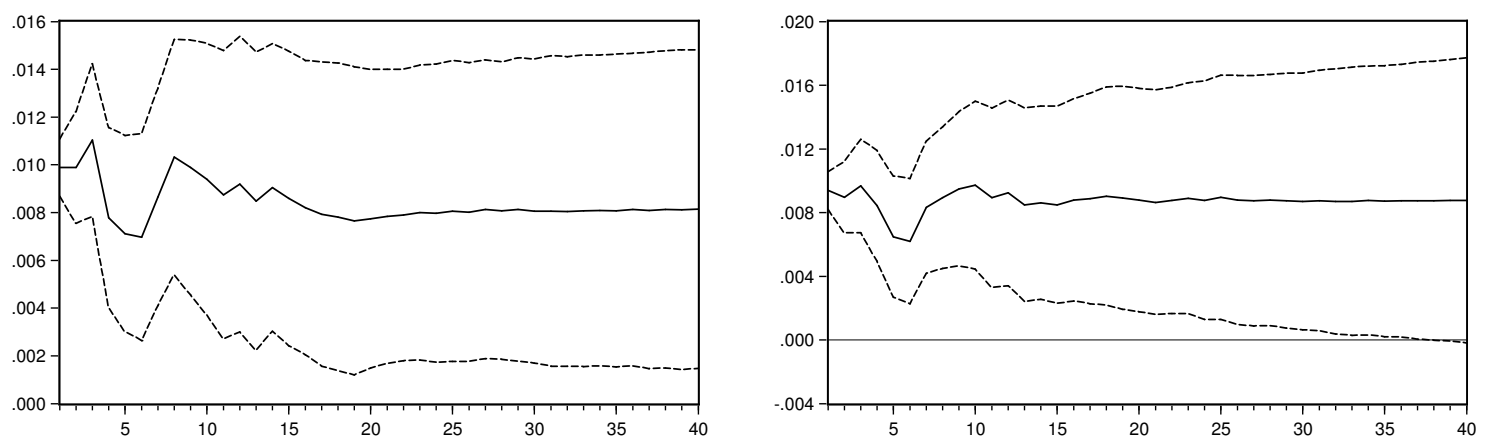

Figure 8 